\title{
Article \\ Phase Transformation of Alumina, Silica and Iron Oxide during Carbothermic Reduction of Fly Ash for Ceramics Production
}

\author{
Qingchun Yu ${ }^{1, *}$, Yong Deng ${ }^{1, *}$, Yuebin Feng ${ }^{2}$ and Ziyong $\mathrm{Li}^{1}$ \\ 1 State Key Laboratory of Complex Nonferrous Metal Resources Clear Utilization, Faculty of Metallurgical and \\ Energy Engineering, Kunming University of Science and Technology, Kunming 650093, China; \\ liziyong918@163.com \\ 2 Faculty of Science, Kunming University of Science and Technology, Kunming 650500, China; fengyb@126.com \\ * Correspondence: 20070154@kust.edu.cn (Q.Y.); dengxinnuo@126.com (Y.D.)
}

check for updates

Citation: Yu, Q.; Deng, Y.; Feng, Y.; Li, Z. Phase Transformation of Alumina, Silica and Iron Oxide during Carbothermic Reduction of Fly Ash for Ceramics Production. Metals 2021, 11, 1165. https:// doi.org/10.3390/met11081165

Academic Editor: Antonio Riveiro

Received: 16 June 2021

Accepted: 19 July 2021

Published: 22 July 2021

Publisher's Note: MDPI stays neutral with regard to jurisdictional claims in published maps and institutional affiliations.

Copyright: (c) 2021 by the authors. Licensee MDPI, Basel, Switzerland. This article is an open access article distributed under the terms and conditions of the Creative Commons Attribution (CC BY) license (https:/ / creativecommons.org/licenses/by/ $4.0 /)$.

\begin{abstract}
Fly ash is a by-product from burning of coal. Utilization of fly ash by carbothermic reduction is an effective way to recover aluminum, silicon, and iron to enhance product-added value. This work is focused on the phase transformation of $\mathrm{Al}_{2} \mathrm{O}_{3}, \mathrm{SiO}_{2}$ and $\mathrm{Fe}_{2} \mathrm{O}_{3}$ during carbothermic reduction of fly ash in air. A comparative analysis of carbothermic reduction of fly ash in air and in nitrogen was made. Thermodynamics analysis was performed to illustrate the possible reactions for residue and condensate. X-ray diffraction (XRD), scanning electronic microscope (SEM), and energy dispersive spectrometry (EDS) were employed to characterize the phase composition, surface morphology, and microstructure of the reduced products. Results show that $\mathrm{Fe}_{3} \mathrm{Si}$ and $\mathrm{Fe}_{2} \mathrm{Si}$ appear sequentially with increasing of temperature. $\mathrm{Al}_{5} \mathrm{O}_{6} \mathrm{~N}$ is an intermediate compound. Residue of $\mathrm{Al}_{9} \mathrm{FeSi}_{3}, \mathrm{Al}$, and $\mathrm{Si}$, and condensate of $\mathrm{SiC}, \mathrm{AlN}$ and $\mathrm{C}$ are obtained. $\beta$-SiAlON was not found in the residue. Nitrogen is involved in the reduction of $\mathrm{Al}_{2} \mathrm{O}_{3}$ but not in the reduction of $\mathrm{SiO}_{2}$ and $\mathrm{Fe}_{2} \mathrm{O}_{3}$. Carbothermic reduction of fly ash in air did not behave the same as fly ash in nitrogen.
\end{abstract}

Keywords: fly ash; vapor; metallic aluminum; nitridation; whisker; alloy; ceramics

\section{Introduction}

Fly ash emerges as a by-product mainly from the combustion of raw coal in thermal power plants. It has been reported that the present accumulating amount of fly ash in China had reached three billion tons 2020, which has resulted in serious environment pollution [1]. Only a small amount is re-utilized in low value-added products, such as concrete, brick, or cement production, and the remainder is directly impounded or landfilled. Fly ash contains mostly aluminosilicate mineral [2,3] and small amounts of iron oxide. On the profitable side, fly ash can be considered a mineral resource if the potential metal values are exploited [4-7]. Carbothermic reduction of fly ash to recover aluminum, silicon and iron can not only increase extra value of products but also reduce environmental pollution.

It was found that reduction of alumina using carbon as a reductant was favored in the presence of limited amounts of oxygen [8]. Alumina [9] decomposes into Al-containing gases and oxygen, then carbon reacts with oxygen to reduce oxygen partial pressure. The Al-containing gases reacted further to produce the final products of $\mathrm{Al}_{4} \mathrm{C}_{3}$ and $\mathrm{Al}_{4} \mathrm{CO}_{4}$. Apart from $\mathrm{Si}, \mathrm{SiC}$ was obtained from the reduction of silica [10]. Carbothermic reduction of alumina improved dramatically during co-reduction of alumina and silica [11]. The presence of silicon in the system reduced the evaporation degree of aluminum [12]. Such a process could achieve advantages at the cost of course of producing an Al-Si master alloy instead of pure aluminum.

As carbothermic reduction of alumina and silica is carried out in nitrogen, the elevated nitrogen pressure [13] is beneficial for preparing coarser AlN particles; however, Forslund [14] pointed out that the conversion decreased with increasing nitrogen addition. $\mathrm{Si}_{3} \mathrm{~N}_{4}$ is produced when silica is reduced by carbon in a flow of nitrogen [15]. Vlasova [16] 
found that $\alpha-\mathrm{Si}_{3} \mathrm{~N}_{4}$ is prepared under the condition in excess amount of carbon, and preparation of $\beta-\mathrm{Si}_{3} \mathrm{~N}_{4}$ is promoted by Si-O-N intermediate in the absence of carbon.

When fly ash was reduced by carbon in air, Al-Si-Fe alloy was obtained at $2273 \mathrm{~K} \mathrm{[17].}$ Raw materials such as hematite [18] or iron [19] were added to reduce the initial reaction temperature of carbothermic reduction of fly ash. In addition, bauxite could be added in order to increase the aluminum content [20]. However, under a temperature of $1873 \mathrm{~K}$, fly ash could be used to prepare mullite with $5 \mathrm{wt} \%$ starch in air [21]. The $\mathrm{NaCl}-\mathrm{KCl}$ molten salts medium reduced the carbothermic reduction temperature of fly ash effectively [22]. If waste with similar chemical components was used, such as red mud [23], $\mathrm{SiC} /$ mullite composite porous ceramics could be prepared under the optimal conditions having $15 \mathrm{wt} \%$ graphite and sintered at $1350{ }^{\circ} \mathrm{C}$ in air.

SiAlON was synthesized when fly ash was reduced by carbon in nitrogen [24]. Qiu et al. [25] found that SiAlON whiskers could be produced under conditions of lower temperature or shorter nitridation time with addition of decomposable additives. Fang et al. [26] found that alumina produced by the decomposition of mullite was partly soluted to $\beta$-SiAlON. Silica in fly ash favorably reacted with excess carbon to form $\mathrm{SiC}$ during the process of carbothermic reduction, and then the product was completely consumed by reaction with mullite to produce $\beta$-Sialon phases [27]. With the increase of mass ratio of $\mathrm{SiO}_{2} / \mathrm{Al}_{2} \mathrm{O}_{3}$, the generated $\mathrm{SiC}$ changed into $\mathrm{Si}_{2} \mathrm{ON}_{2}$ [28]. However, if carbothermic reduction of fly ash was in argon atmosphere, $\mathrm{SiC}$ was the final product [29].

Fly ash contains minor constituents such as iron oxide. Iron oxide can be completely reduced by carbon [30] at a relatively lower temperature. Accordingly, iron in the product affects the reduction of alumina and silica. Meanwhile, as fly ash is reduced by carbon in air, nitrogen will inevitably take part in the reaction. Most aluminosilicate ceramics have been prepared in nitrogen. Although there is nitrogen in air, different products are produced after carbothermic reduction of fly ash in nitrogen and in air. Atmosphere shows unavoidable impact on the carbothermic reduction of fly ash. Few studies have reported the synthesis of $\beta-\mathrm{SiAlON}$ in air. As discussed above, the progress of a carbothermic reduction reaction is greatly influenced by the temperature and reduction atmosphere. In this work, the phase transformation of alumina, silica and iron oxide were investigated according to the phase analysis of the reduced product of fly ash at different temperatures. Comparison of carbothermic reduction of fly ash in air and in nitrogen was performed to better understand the effect of atmosphere.

\section{Materials and Methods}

\subsection{Raw Materials}

Fly ash from a thermal power plant in Taiyuan, Shanxi province in China was ground and screened through a standard sieve to obtain powders of 100 mesh. The chemical composition of fly ash is shown in Table 1. The X-ray diffraction pattern of fly ash is presented in Figure 1. It was observed that fly ash consists of major phases of mullite $\left(3 \mathrm{Al}_{2} \mathrm{O}_{3} \bullet 2 \mathrm{SiO}_{2}\right)$ and silica $\left(\mathrm{SiO}_{2}\right)$ and a minor phase of iron oxide $\left(\mathrm{Fe}_{2} \mathrm{O}_{3}\right)$. Charcoal has the characteristics of high fix carbon, porosity, and low ash. Charcoal from Kunming Iron and Steel Holding Co., Ltd was used as a carbonaceous reducing agent. Calcium lignosulphonate $\left(\mathrm{C}_{20} \mathrm{H}_{24} \mathrm{CaO}_{10} \mathrm{~S}_{2}\right)$ from a paper mill was used as a binder. Industrial parameters of charcoal, such as moisture $\left(\mathrm{M}_{\mathrm{ad}}\right)$, volatiles $\left(\mathrm{V}_{\mathrm{ad}}\right)$, coal ash $\left(\mathrm{A}_{\mathrm{ad}}\right)$, fixed carbon $\left(\mathrm{FC}_{\mathrm{ad}}\right)$, and ash composition, are shown in Table 2.

Table 1. Chemical composition of fly ash (wt $\%)$.

\begin{tabular}{cccccccccc}
\hline Composition & $\mathrm{Al}_{\mathbf{2}} \mathrm{O}_{3}$ & $\mathrm{SiO}_{2}$ & $\mathrm{Fe}_{\mathbf{2}} \mathrm{O}_{\mathbf{3}}$ & $\mathbf{C a O}$ & $\mathrm{TiO}_{2}$ & $\mathbf{M g O}$ & $\mathbf{M n O}$ & $\mathrm{C}$ & Others \\
\hline Content $(w \mathrm{t} \%)$ & 30.46 & 45.60 & 3.00 & 2.32 & 0.92 & 0.50 & 0.03 & 4.18 & 12.99 \\
\hline
\end{tabular}




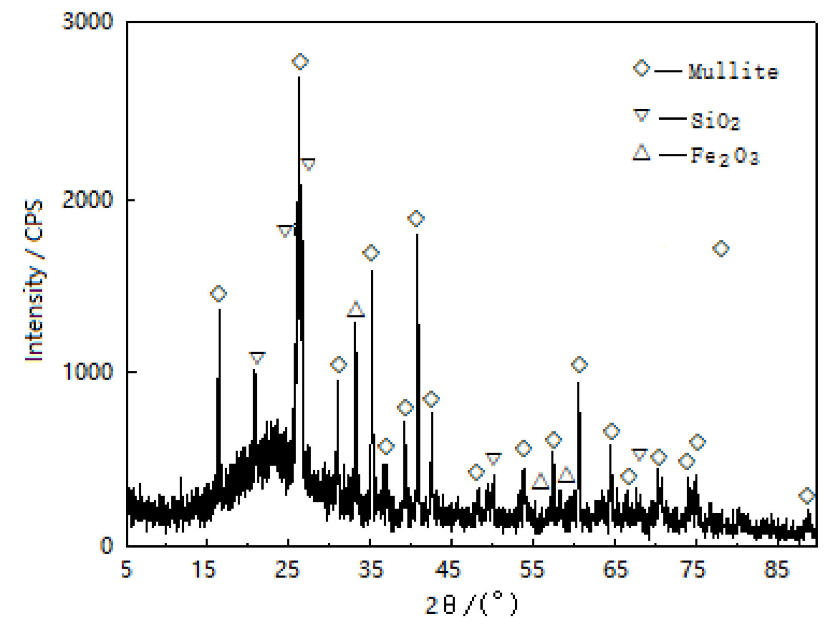

Figure 1. XRD pattern of coal fly ash.

Table 2. Industrial analysis of charcoal.

\begin{tabular}{ccccc}
\hline Property Index & $\mathbf{M}_{\mathbf{a d}}$ & $\mathbf{A}_{\mathbf{a d}}$ & $\mathbf{V}_{\mathbf{a d}}$ & $\mathbf{F C}_{\mathbf{a d}}$ \\
\hline Index value $w \mathrm{t} \%$ (air-dry basis) & 13.0 & 5.61 & 6.55 & 87.84 \\
\hline
\end{tabular}

\subsection{Experimental Setup}

Experiments were carried out in a high-frequency induction furnace with a maximum operating temperature of $2473 \mathrm{~K}$. the schematic of the setup is shown in Figure 2. The furnace includes a power supply unit, an infrared thermometer, and a heating device. The power supply unit provides both power and electrical control. The infrared thermometer is used for the temperature measurement. The heating device consists of a graphite crucible, a refractory filler, and an insulation layer, and a heating coil. The heating coil is cooled by circulating water.

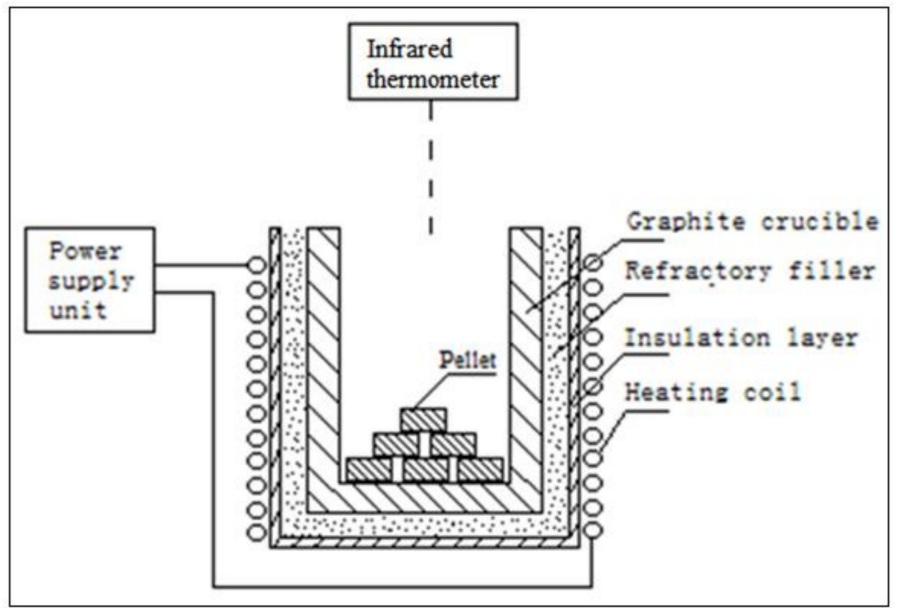

Figure 2. Schematic of high frequency induction furnace.

\subsection{Experimental Procedure}

Raw materials have to be pelletized to achieve good gas permeability during the carbothermic reduction of fly ash. After examination and determination of some main relevant parameters (properties of the pellets, stoichiometric carbon addition, binder addition), the chemical composition of the raw materials combined with the optimal utilization of the setup has been investigated and improved to produce an alloy. In the experiment the refractory filler would melt if the heating time was more than half an hour 
at $2473 \mathrm{~K}$. Therefore, the reaction temperature should be kept below $2473 \mathrm{~K}$. In order to evaluate the consumption of graphite crucible caused by the reduction of fly ash, pellets consisting entirely of fly ash were heated up to $2273 \mathrm{~K}$. No metallic phase was found. This meant that the effect of graphite crucible on the carbothermic reduction of fly ash could be neglected.

Pellets suffered a great mass loss. In fact, the mass loss caused by the reduction of alumina, silica, and iron oxide; decomposition of chemicals; or evaporation of volatiles reached $50 \%$ at most. Material-spraying is one of the most serious problems. Therefore, addition of raw materials was based on the complete reduction of metal oxides, except $\mathrm{MnO}$ (see Table 1), in 100g fly ash to generate enough products. By calculation, the stoichiometric addition of charcoal is $30 \mathrm{~g}$. Binder and water account for 6.5 and 13.7 percent of fly ash, respectively. A good intermixing of fly ash, charcoal powder, and binder was provided by uniformly mixing with water. During mixing, proportionate ingredients were combined till the required consistency was achieved. The mixture was then pressed with an external compaction in a stainless-steel die to form cylindrical pellets of $\Phi 20 \times 25 \mathrm{~mm}$, and dried at $150{ }^{\circ} \mathrm{C}$ for $24 \mathrm{~h}$ to remove moisture. A graphite crucible loaded with samples was placed into the furnace and heated to a pre-set temperature. Carbothermic reduction of fly ash proceeded continuously for $40 \mathrm{~min}$ to ensure a complete reduction of fly ash. After the experiments, the graphite crucible was immediately removed from the furnace and cooled at room temperature. The graphite crucible was split down the middle vertically with a saw. Residue and condensate were separated and analyzed. A flowsheet of carbothermic reduction of fly ash is shown in Figure 3.

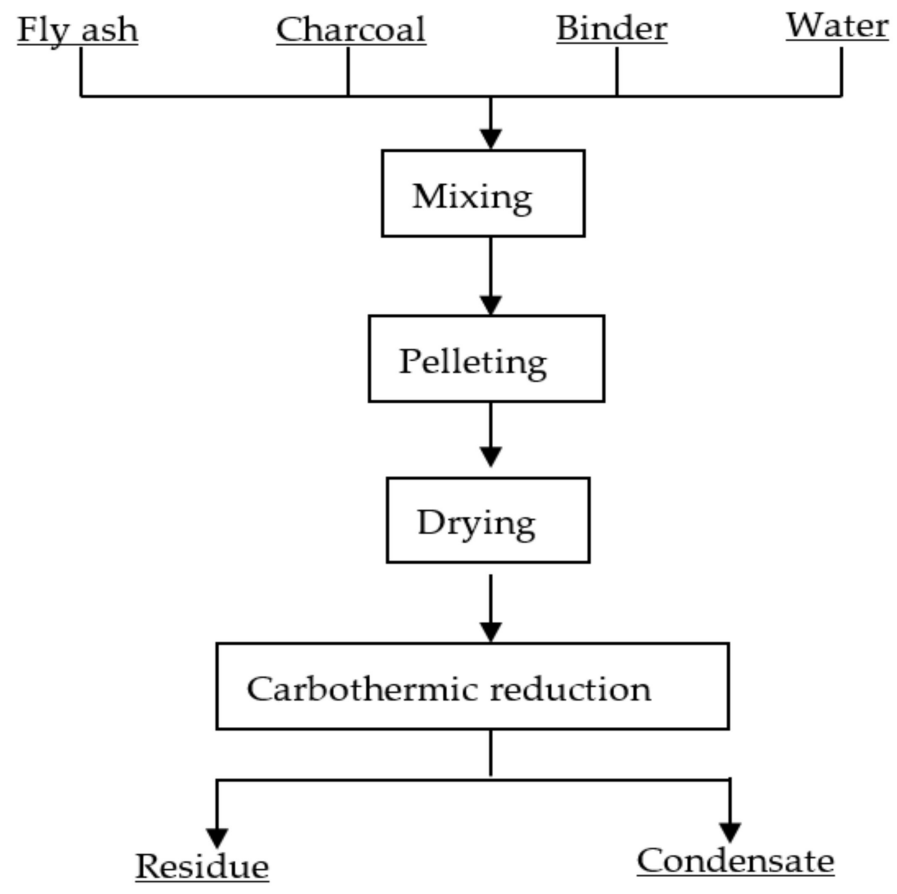

Figure 3. A flowsheet of carbothermic reduction of fly ash in the air.

\subsection{Analysis Methods}

The internal-standard technique is currently the best method for quantitative X-ray diffraction analysis. It adopts the usual procedure of constructing a calibration curve from standards for each component sought, which is tedious, especially for multicomponent analysis. Chung [31,32] derived an intensity-concentration equation free from matrix effect. For the quantitative X-ray diffraction analysis of a mixture of $n$ components, unknowns $\left(X_{i}, i=1 \ldots j \ldots n\right)$ must satisfy the following $(n+1)$ equations:

$$
I_{1}=k_{1} \cdot X_{1}
$$




$$
\begin{gathered}
I_{2}=k_{2} \cdot X_{2} \\
\vdots \\
I_{n}=k_{n} \cdot X_{n} \\
X_{1}+X_{2}+\ldots+X_{n}=1
\end{gathered}
$$

where $I_{n}$ is the intensity of X-rays of component $i, X_{i}$ is the weight fraction of component $\mathrm{i}$, and $k_{i}$ is a factor containing the mass absorption coefficient of the total sample. At this moment, $k_{i}$ is constant for a very small variation in $X_{i} . k_{i}$ in the ratio $k_{i} / k_{j}$ is constant for any $X_{i}$. The plot of intensity ratio $\left(I_{i} / I_{j}\right)$ to the weight ratio $\left(X_{i} / X_{j}\right)$ of any two components is a straight line, which can provide a quantitative analysis of the processed samples.

The chemical composition of fly ash was determined by chemical analysis. Industrial parameters of charcoal measured by the national standard of the People's Republic of China [33]. Crystalline phases were identified by X-ray diffractometer (XRD: PANALYTICAL, EMPYREAN, Cu-K $\alpha$ radiation). Scanning electron microscopy with an energy dispersive spectrometer (SEM-EDS: JEOL, JSM-6510LV) was used to examine surface morphology, microstructure and micro-area elemental composition of the reduced products.

\section{Thermodynamics Analysis}

Fly ash is a product of coal combustion at high temperature. The existing form of fly ash will maintain the status of coal after combustion within a certain temperature range. The transformation of coal mineral during combustion can be modeled as a mixture of individual minerals before $1500 \mathrm{~K}$ [34]. With increasing temperature, a number of liquid and solid solutions could possibly be formed over the reaction conditions. However, the formation of liquid and solid solutions was considered to have no significant effects on the equilibrium composition of the products $[35,36]$. Therefore, on the basis of the carbothermic reduction of alumina, silica, and iron oxide, a thermodynamic analysis of carbothermic reduction of fly ash was made. The carbothermic reduction temperature of fly ash is far more than $1273 \mathrm{~K}$. CO predominates in the atmosphere [37,38]. Consequently, the formation of carbon dioxide was not considered.

Reactions (1-13), concerning the residue and the condensate from literatures $[1,18,39]$ are presented in Table 3. The relationships between change of Gibbs free energy and temperature were obtained using HSC 6.0 and Origin 7.0 software. Figure 4a shows that Gibbs free energy of the reactions (1-4) and (6-8) decreased with increasing temperature. The initial temperatures of reactions (1-3) were $1802 \mathrm{~K}, 1941 \mathrm{~K}$, and $1837 \mathrm{~K}$, respectively, suggesting carbothermic reduction of silica by the reaction (1) occurs with the most spontaneous tendency with increasing temperature. Iron oxide was readily reduced to iron by reaction (4) over $917 \mathrm{~K}$. Fe 3 Si was produced by reaction (5) in the temperature range of 1711-2449 K. It is clear that Fe lowers the reduction temperature of silica compared with the reaction (2). The initial temperatures of reactions (6-7) were $2167 \mathrm{~K}$ and $1969 \mathrm{~K}$, respectively. It can be inferred that alumina is prone to carbothermic nitridation below $1969 \mathrm{~K}$. The generated $\mathrm{AlN}$ reacted with $\mathrm{SiC}$ to produce $\mathrm{Al}$ and $\mathrm{Si}$ by reaction (8) above $1846 \mathrm{~K}$. 
Table 3. Chemical reactions and fitting formula of $\Delta_{\mathrm{r}} \mathrm{G}^{\Theta}-\mathrm{T}$.

\begin{tabular}{|c|c|c|c|}
\hline Category & Number & Reaction Equations & Fitting Formula of Standard Free Energy, $\mathrm{kJ}^{\circ} \mathrm{mol}^{-1}$ \\
\hline \multirow{8}{*}{ Residue } & $(1)$ & $\mathrm{SiO}_{2}+3 \mathrm{C}=\mathrm{SiC}+2 \mathrm{CO}(\mathrm{g})$ & \multirow{8}{*}{$\begin{array}{c}\Delta_{\mathrm{r}} \mathrm{G}^{\circ}=593.5582-0.3293 \mathrm{~T} \\
\Delta_{\mathrm{r}} \mathrm{G}^{\circ}=683.6557-0.3523 \mathrm{~T} \\
\Delta_{\mathrm{r}} \mathrm{G}^{\circ}=1177.8021-0.6410 \mathrm{~T} \\
\Delta_{\mathrm{r}} \mathrm{G}^{\circ}=464.3454-0.5063 \mathrm{~T} \\
\Delta_{\mathrm{r}} \mathrm{G}^{\circ}=534.4661-0.3123 \mathrm{~T}(873.15-2073.15 \mathrm{~K}) \\
\Delta_{\mathrm{r}} \mathrm{G}^{\circ}=-626.5703+0.2558 \mathrm{~T}(2073.15-2473.15 \mathrm{~K}) \\
\Delta_{\mathrm{r}} \mathrm{G}^{\circ}=794.3620-0.3665 \mathrm{~T} \\
\Delta_{\mathrm{r}} \mathrm{G}^{\circ}=678.3700-0.3445 \mathrm{~T} \\
\Delta_{\mathrm{r}} \mathrm{G}^{\circ}=631.6170-0.3421 \mathrm{~T}\end{array}$} \\
\hline & (2) & $\mathrm{SiO}_{2}+2 \mathrm{C}=\mathrm{Si}+2 \mathrm{CO}(\mathrm{g})$ & \\
\hline & (3) & $3 \mathrm{SiO}_{2}+6 \mathrm{C}+2 \mathrm{~N}_{2}(\mathrm{~g})=\mathrm{Si}_{3} \mathrm{~N}_{4}+6 \mathrm{CO}(\mathrm{g})$ & \\
\hline & (4) & $\mathrm{Fe}_{2} \mathrm{O}_{3}+3 \mathrm{C}=2 \mathrm{Fe}+3 \mathrm{CO}(\mathrm{g})$ & \\
\hline & (5) & $\mathrm{SiO}_{2}+2 \mathrm{C}+3 \mathrm{Fe}=\mathrm{Fe}_{3} \mathrm{Si}+2 \mathrm{CO}(\mathrm{g})$ & \\
\hline & (6) & $2 \mathrm{Al}_{2} \mathrm{O}_{2}+3 \mathrm{C}=\mathrm{Al}_{1} \mathrm{CO}_{1}+2 \mathrm{CO}(\mathrm{o})$ & \\
\hline & $\begin{array}{l}\text { (b) } \\
(7)\end{array}$ & 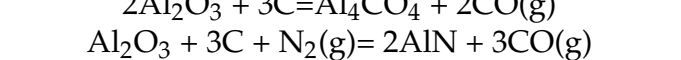 & \\
\hline & (8) & $2 \mathrm{AlN}+\mathrm{SiC}+1 / 2 \mathrm{O}_{2}=2 \mathrm{Al}+\mathrm{Si}+\mathrm{N}_{2}(\mathrm{~g})+\mathrm{CO}(\mathrm{g})$ & \\
\hline \multirow{5}{*}{ Condensate } & (9) & $\mathrm{SiO}_{2}+\mathrm{C}=\mathrm{SiO}(\mathrm{g})+\mathrm{CO}(\mathrm{g})$ & $\Delta_{\mathrm{r}} \mathrm{G}^{\circ}=672.8021-0.3305 \mathrm{~T}$ \\
\hline & $(10)$ & $\mathrm{SiO}(\mathrm{g})+2 \mathrm{C}=\mathrm{SiC}+\mathrm{CO}(\mathrm{g})$ & $\Delta_{\mathrm{r}} \mathrm{G}^{\circ}=-79.2431+0.0011 \mathrm{~T}$ \\
\hline & $(11)$ & $\mathrm{Al}(\mathrm{g})+\mathrm{N}_{2}(\mathrm{~g})=2 \mathrm{AlN}$ & $\Delta_{\mathrm{r}} \mathrm{G}^{\circ}=-1273.7815+0.4568 \mathrm{~T}$ \\
\hline & (12) & $\mathrm{Al}_{2} \mathrm{O}_{3}+2 \mathrm{C}=\mathrm{Al}_{2} \mathrm{O}(\mathrm{g})+2 \mathrm{CO}(\mathrm{g})$ & $\Delta_{\mathrm{r}} \mathrm{G}^{\circ}=1263.5383-0.5370 \mathrm{~T}$ \\
\hline & (13) & $\mathrm{Al}_{2} \mathrm{O}(\mathrm{g})+\mathrm{C}+\mathrm{N}_{2}=2 \mathrm{AlN}+\mathrm{CO}(\mathrm{g})$ & $\Delta_{\mathrm{r}} \mathrm{G}^{\circ}=-585.1690+0.1924 \mathrm{~T}$ \\
\hline
\end{tabular}

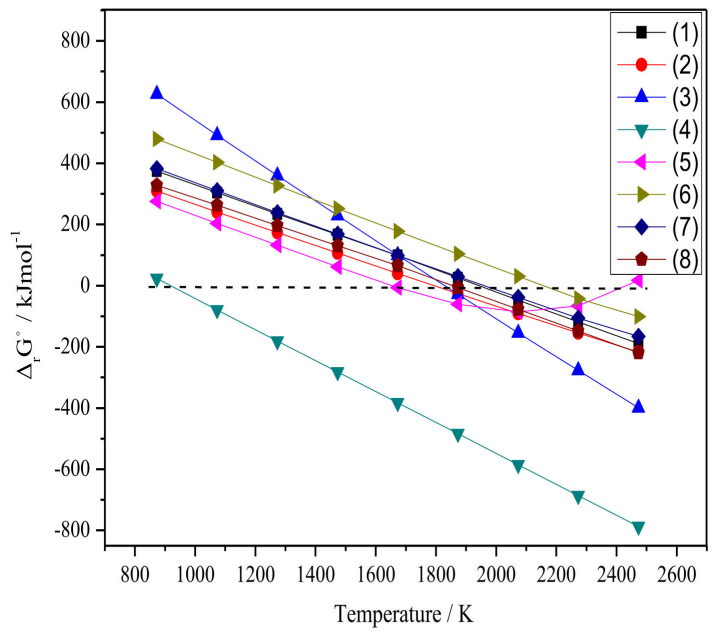

(a)

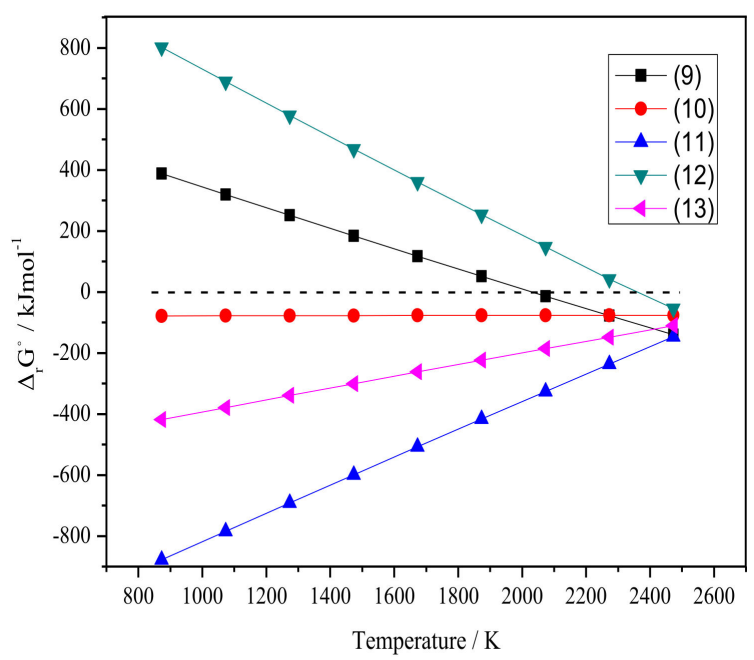

(b)

Figure 4. Diagrams of standard free energy versus temperature for reactions (1-13): (a) reactions of (1-8), (b) reactions of (9-13).

Reaction (9) took place above $2036 \mathrm{~K}$ and progressed more and more with the increase of temperature. It was expected that the generated $\mathrm{SiO}$ would react with $\mathrm{C}$ to produce $\mathrm{SiC}$, because the reaction (10) always happens according to the Gibbs free energy values as shown in Figure $4 \mathrm{~b}$. Gaseous aluminum caused by the volatilization of metallic aluminum reacted with nitrogen by reaction (11) at all the temperatures studied. Meanwhile, another possible way to produce AlN is carbothermic reduction of alumina by reaction (12) following carbothermic nitridation of $\mathrm{Al}_{2} \mathrm{O}$ by reaction (13). The initial temperature of reaction (12) is $2353 \mathrm{~K}$. In addition, from the viewpoint of kinetics, gas diffusion caused by reaction (11) is far more than the solid diffusion caused by reaction (12). Therefore, production of AlN by reaction (11) takes precedence over reaction (12).

\section{Results and Discussion}

\subsection{Effect of Temperature on Phase Transformation of $\mathrm{Al}_{2} \mathrm{O}_{3}, \mathrm{SiO}_{2}$, and $\mathrm{Fe}_{2} \mathrm{O}_{3}$}

XRD analysis of the residues after carbothermic reduction of fly ash at different temperatures was made to illustrate the phase transformation of alumina, silica and iron oxide. As shown in Figure 5, it was observed that the phases are mullite $\left(3 \mathrm{Al}_{2} \mathrm{O}_{3} \cdot 2 \mathrm{SiO}_{2}\right)$, 
silica, iron oxide, and carbon at $1373 \mathrm{~K}$ and $1473 \mathrm{~K}$, which was consistent with the original samples. The diffraction peaks of silica and mullite existed at $1573 \mathrm{~K}$ and $1673 \mathrm{~K}$, but iron oxide did not, which means reduction of iron oxide occurred. Reduction of silica and alumina doesn't take place. With the increase of temperature, the peak intensity of mullite and silica decreased prominently, and new diffraction peaks of SiC and alumina appeared at $1773 \mathrm{~K}$. It was clear that mullite decomposed into $\mathrm{Al}_{2} \mathrm{O}_{3}$ and silica, and silica was reduced to $\mathrm{SiC}$.

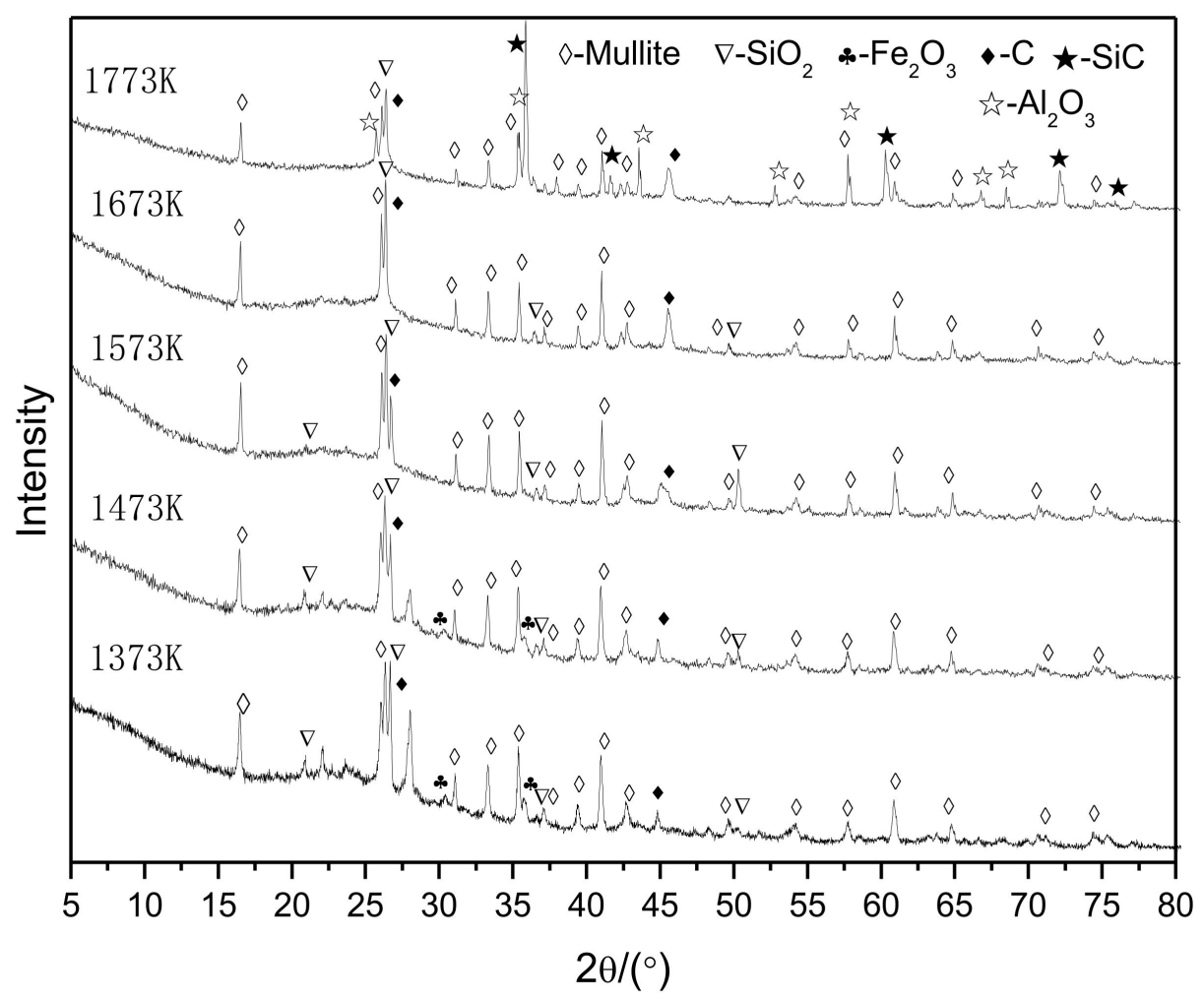

Figure 5. XRD patterns of residues at $1373 \mathrm{~K} \sim 1773 \mathrm{~K}$.

Figure 6 shows diffraction patterns of the residues in the temperature range of $1873-2273 \mathrm{~K}$. It was found that the residue contained $\mathrm{Al}_{2} \mathrm{O}_{3}, \mathrm{SiC}$, and $\mathrm{Fe}_{3} \mathrm{Si}$ at $1873 \mathrm{~K}$. The increasing peak intensity of alumina matched the disappearance of mullite due to its decomposition. The generated silica and original silica were both reduced into $\mathrm{SiC}$ and $\mathrm{Fe}_{3} \mathrm{Si}$ by reactions (1) and (5), respectively. Thermodynamic comparative analysis of the reactions between (2) and (5) showed that the presence of Fe reduced the reduction temperature of silica. However, an Si phase was not observed at $1873 \mathrm{~K}$.

At $1973 \mathrm{~K}$ the decrease of peak intensity of alumina revealed that the reduction of alumina occurred. $\mathrm{Fe}_{2} \mathrm{Si}$ phase was detected. If $\mathrm{Fe}_{2} \mathrm{Si}$ was produced by an individual reaction, the newly generated $\mathrm{Fe}_{2} \mathrm{Si}$ and already generated $\mathrm{Fe}_{3} \mathrm{Si}$ at $1873 \mathrm{~K}$ remained in the reduced sample. Given the disappearance of $\mathrm{Fe}_{3} \mathrm{Si}$ diffraction peak, it is possible to conclude that the generated $\mathrm{Si}$ dissolves into $\mathrm{Fe}_{3} \mathrm{Si}$ phase to produce $\mathrm{Fe}_{2} \mathrm{Si}$. Accordingly, it could be found that the diffraction peak of $\mathrm{Fe}_{2} \mathrm{Si}$ widened and shifted towards a high angle in comparison with that at $1873 \mathrm{~K}$, which is consistent with the decrease of the lattice constant of iron [40]. The appearance of a $\mathrm{Al}_{5} \mathrm{O}_{6} \mathrm{~N}$ diffraction peak means nitrogen in air is involved in chemical reactions as a result of carbothermic reduction. This can be explained by the fact that nitrogen reacts with $\mathrm{Al}_{2} \mathrm{O}_{3}$ to produce $\mathrm{AlN}$ by the reaction (7), then the generated $\mathrm{AlN}$ reacts with $\mathrm{Al}_{2} \mathrm{O}_{3}$ to produce $\mathrm{Al}_{5} \mathrm{O}_{6} \mathrm{~N}$ [41-43]. 


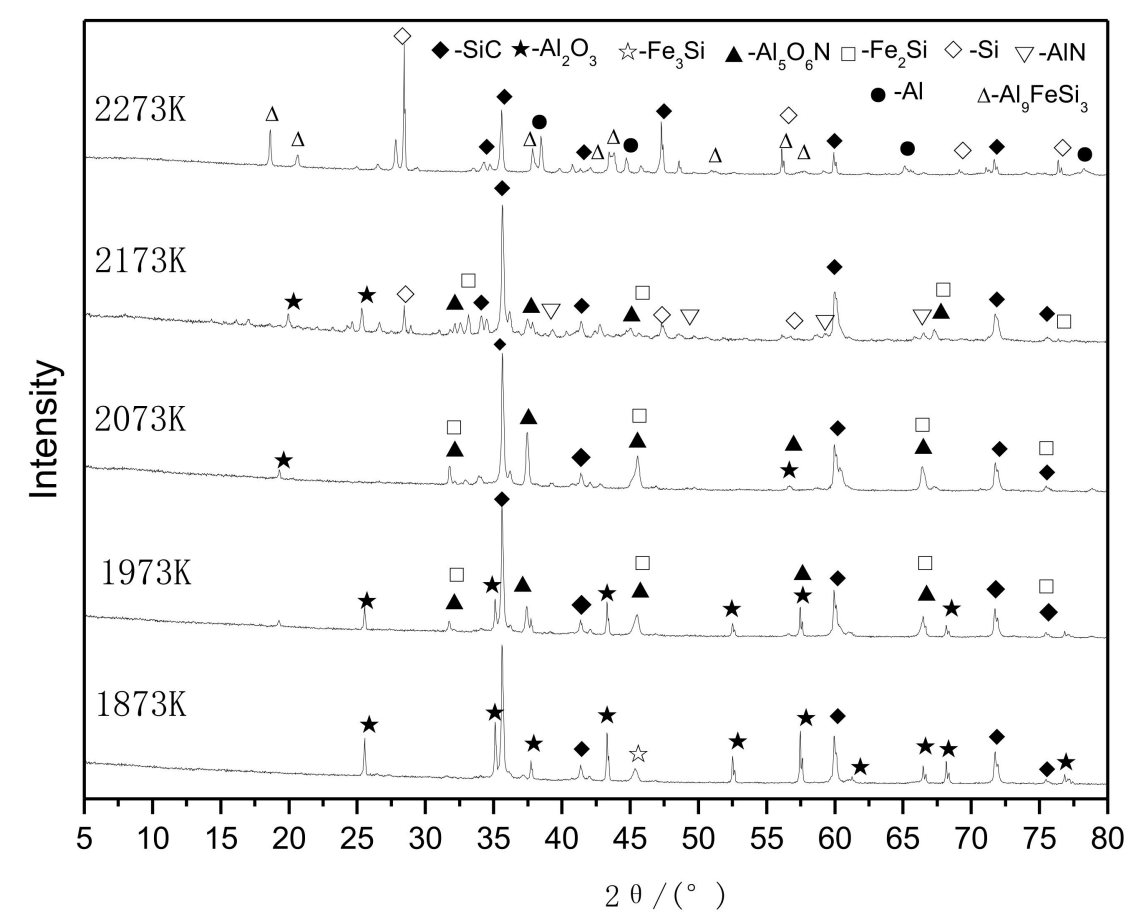

Figure 6. XRD patterns of the residues at $1873 \mathrm{~K} \sim 2273 \mathrm{~K}$.

A stronger diffraction peak of $\mathrm{Fe}_{2} \mathrm{Si}$ appeared at $2073 \mathrm{~K}$, suggesting more and more $\mathrm{Si}$ was produced and dissolved into the $\mathrm{Fe}_{3} \mathrm{Si}$ phase. The increase of $\mathrm{Al}_{5} \mathrm{O}_{6} \mathrm{~N}$ peak intensity coincided with the decrease of alumina peak intensity because of the reaction between AlN and $\mathrm{Al}_{2} \mathrm{O}_{3}$. Si and $\mathrm{AlN}$ were detected in the residue at $2173 \mathrm{~K}$. With the increase of $\mathrm{Al}_{2} \mathrm{O}_{3}$ peak intensity, the decrease of $\mathrm{Al}_{5} \mathrm{O}_{6} \mathrm{~N}$ peak intensity showed that $\mathrm{Al}_{5} \mathrm{O}_{6} \mathrm{~N}$ were decomposed into $\mathrm{AlN}$ and $\mathrm{Al}_{2} \mathrm{O}_{3}[44,45]$. The peak intensity of $\mathrm{SiC}$ decreased progressively, which is in accordance with the appearance of a weak diffraction peak of $\mathrm{Si}$ according to reaction (8).

At $2273 \mathrm{~K}$ diffraction peaks of $\mathrm{Al}_{2} \mathrm{O}_{3}, \mathrm{Al}_{5} \mathrm{O}_{6} \mathrm{~N}$, $\mathrm{AlN}$ and $\mathrm{Fe}_{2} \mathrm{Si}$ were not found in the residue; however, $\mathrm{Al}$ and $\mathrm{Al}_{9} \mathrm{FeSi}_{3}$ peaks were. The disappearance of the $\mathrm{Al}_{5} \mathrm{O}_{6} \mathrm{~N}$ diffraction peak indicated that $\mathrm{Al}_{5} \mathrm{O}_{6} \mathrm{~N}$ was decomposed. The generated $\mathrm{Al}_{2} \mathrm{O}_{3}$ was transformed into AlN by reaction (7), which sequentially reacted with $\mathrm{SiC}$ to produce $\mathrm{Al}$ and $\mathrm{Si}$ by reaction (8). The speculation coincided with the decrease of peak intensity of $\mathrm{SiC}$ and the increase of peak intensity of $\mathrm{Al}$ and $\mathrm{Si}$. It can be inferred that $\mathrm{AlN}$ promotes production of $\mathrm{Al}$ and $\mathrm{Si}$. The generated $\mathrm{Al}$ and $\mathrm{Si}$ will react with the already disappeared $\mathrm{Fe}_{2} \mathrm{Si}$ to produce $\mathrm{Al}_{9} \mathrm{FeSi}_{3}$.

Based on the discussion above, it was found that the phase transformation of $\mathrm{Al}_{2} \mathrm{O}_{3}$, $\mathrm{SiO}_{2}$, and $\mathrm{Fe}_{2} \mathrm{O}_{3}$ during the carbothermic reduction of fly ash in air could be divided into four stages in terms of temperature: (1) iron oxide was reduced in the temperature range of $1373 \mathrm{~K} \sim 1573 \mathrm{~K}$; (2) decomposition of mullite $\left(3 \mathrm{Al}_{2} \mathrm{O}_{3} \cdot 2 \mathrm{SiO}_{2}\right)$ and reduction of silica occurred at temperatures between $1673 \mathrm{~K}$ and $1873 \mathrm{~K}$; (3) the formation and decomposition of $\mathrm{Al}_{5} \mathrm{O}_{6} \mathrm{~N}$ took place within $1973 \mathrm{~K} \sim 2173 \mathrm{~K}$; (4) $\mathrm{Al}_{9} \mathrm{FeSi}_{3}, \mathrm{Al}$, and $\mathrm{Si}$ were obtained at $2273 \mathrm{~K}$.

\subsection{Surface Morphology and Phase Analysis}

\subsubsection{Residue}

Figure 7a presents the cross-section morphology of residue at the bottom of crucible after experiment at $2273 \mathrm{~K}$. Three sections with different colors are labeled as A, B, and C, respectively. EDS of the sections A, B, and C are shown in Figure $7 \mathrm{~b}-\mathrm{d}$, respectively, and the elemental compositions are shown in Table 4. 


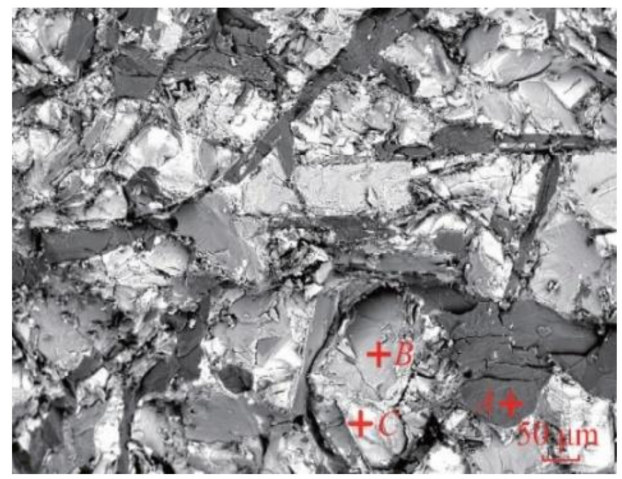

(a)

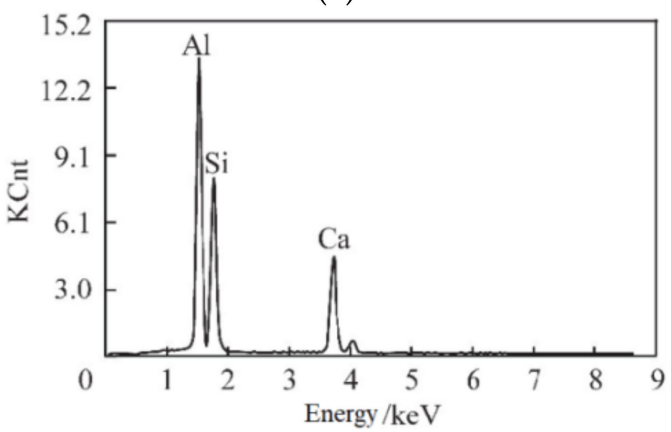

(c)

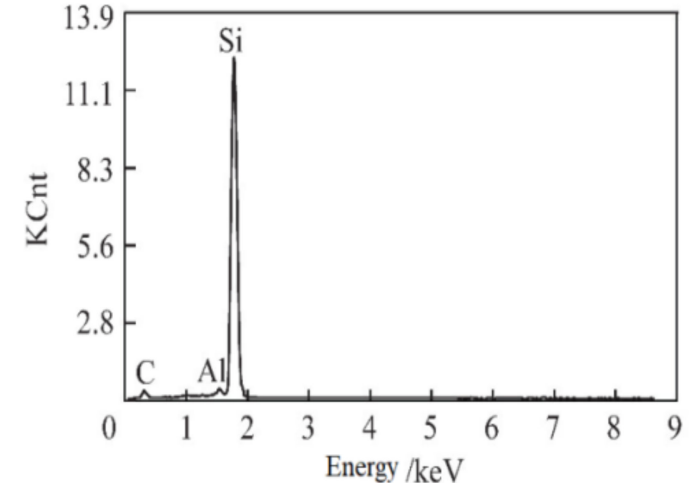

(b)

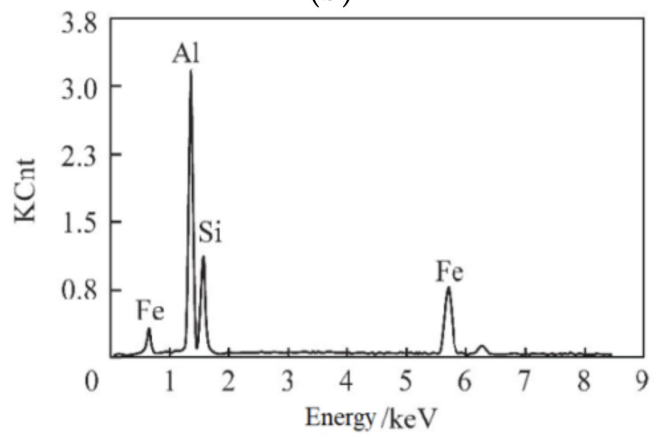

(d)

Figure 7. SEM-EDS patterns of the residue; (a) SEM image of the residue with three sections, (b) EDS of section A, (c) EDS of section B, (d) EDS of section C.

Table 4. Elemental compositions of the sections A, B and C.

\begin{tabular}{ccccccccc}
\hline & A & \multicolumn{3}{c}{ B } & \multicolumn{3}{c}{ C } \\
\hline Element & Mass\% & Atom \% & Element & Mass\% & Atom\% & Element & Mass \% & Atom \% \\
\hline $\mathrm{Al}$ & 1.58 & 1.24 & $\mathrm{Al}$ & 36.96 & 41.09 & $\mathrm{Al}$ & 41.67 & 51.95 \\
$\mathrm{Si}$ & 74.09 & 55.8 & $\mathrm{Si}$ & 36.71 & 39.21 & $\mathrm{Si}$ & 21.68 & 25.97 \\
$\mathrm{C}$ & 24.33 & 42.90 & $\mathrm{Ca}$ & 26.33 & 19.70 & $\mathrm{Fe}$ & 36.65 & 22.09 \\
\hline
\end{tabular}

The grey section marked A contains $\mathrm{Al}, \mathrm{Si}$ and $\mathrm{C}$. The calculated $\mathrm{Si} / \mathrm{C}$ atomic ratio is 1.3 , which is more than the theoretical value of $\mathrm{SiC}$ with $\mathrm{Si} / \mathrm{C}$ atomic ratio of 1 . It can be deduced that an individual $\mathrm{Si}$ phase exists in addition to $\mathrm{SiC}$. The light grey section marked $\mathrm{B}$ contains $\mathrm{Al}, \mathrm{Si}$, and $\mathrm{Ca}$. Calcium comes from fly ash, binder, and ash of charcoal. $\mathrm{Al}, \mathrm{Si}$ and $\mathrm{Fe}$ are found in the silver section marked $\mathrm{C}$. The content of $\mathrm{Fe}$ is much more than the theoretical value of $\mathrm{Al}_{9} \mathrm{FeSi}_{3}$, which puts in evidence that $\mathrm{Fe}$ is excessive in the residue. It was found that $\mathrm{Fe}$ was not distributed among these three sections in a balanced way. It is possible $\mathrm{Fe}_{2} \mathrm{O}_{3}$ in fly ash is reduced first because of the lower reduction temperature. The generated $\mathrm{Fe}$ aggregated into droplets and led to excess of iron in a specific region. Subsequently, the iron-containing phase was formed, seen in $\mathrm{Fe}_{3} \mathrm{Si}_{1} \mathrm{Fe}_{2} \mathrm{Si}$ and $\mathrm{Al}_{9} \mathrm{FeSi}_{3}$. If there were no iron droplets in a specific region, $\mathrm{SiO}_{2}$ and $\mathrm{Al}_{2} \mathrm{O}_{3}$ would be reduced into $\mathrm{Si}$ and $\mathrm{Al}$, respectively, such as in the light grey region marked $\mathrm{B}$.

\subsubsection{Condensate}

During carbothermic reduction of fly ash at $2273 \mathrm{~K}$, a small amount of grey cottonshaped condensatewas produced on the top and wall of crucible. The condensate was composed of $\mathrm{SiC}, \mathrm{AlN}$ and $\mathrm{C}$, as shown in Figure 8a. At high temperatures $\mathrm{SiO}_{2}$ was reduced by carbon to produce gaseous $\mathrm{SiO}$ [46], and the generated $\mathrm{SiO}$ continued to react with carbon to produce $\mathrm{SiC}$ by reaction (10). $\mathrm{Al}_{2} \mathrm{O}_{3}$ was unavailable to react with $\mathrm{C}$ by 
the reaction (12) due to the excessive initial reaction temperature of $2353 \mathrm{~K}$. Production of AlN was more likely to happen by reaction (11) instead of reaction (13). Aluminum vapor required by the reaction (11) came from the volatilization of metallic aluminum [47]. Composite ceramics of AlN-SiC offer the advantages of high thermal conductivity and good mechanical properties [48]. The condensate provides the right material for preparing AlN-SiC composite ceramics by burning the residual carbon. It is noted that the formation of condensate did not always happen. This was closely related to the heating rate.

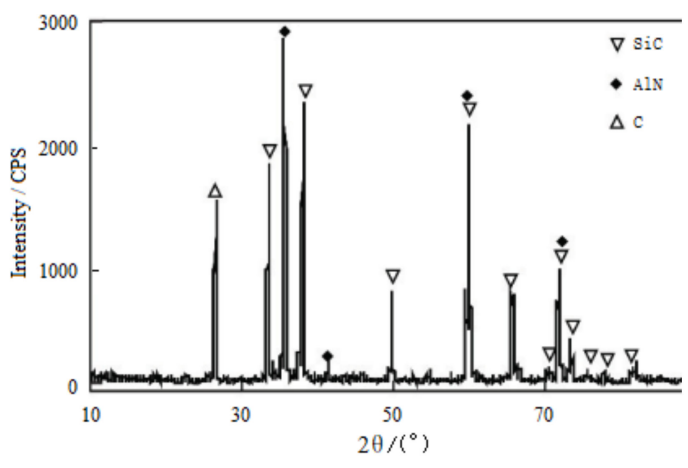

(a)

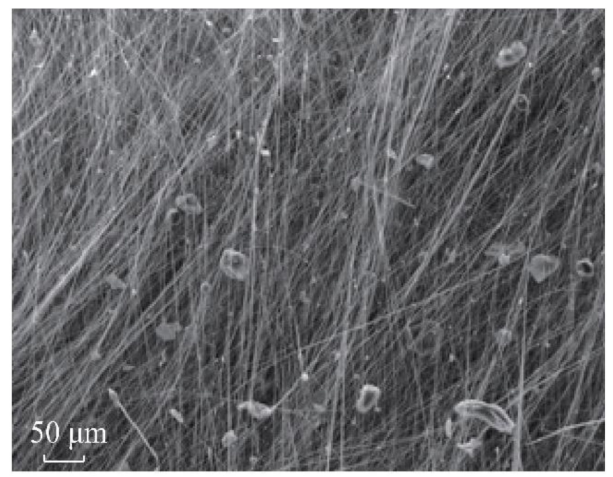

(b)

Figure 8. XRD pattern and SEM image of condensate; (a) XRD patterns of condensate, (b) SEM image of condensate.

The scanning electron microscope image of the condensate shown in Figure 8b indicates that most whiskers have distinct droplets at the top, which is considered to be the main evidence of VLS mechanism (V: vapor feed gases; L: liquid catalyst; S: solid crystalline whisker) $[49,50]$. Al and $\mathrm{SiO}$ vapor phase $[51,52]$ may form an oxygen-rich liquid phase at the top of the whiskers after nucleation, and $C$ can enter the liquid phase and produce $\mathrm{SiC}$ and AlN whiskers by reactions (1) and (7).

\subsection{Phase Transformation Analysis}

The appearance of an $\mathrm{Fe}_{3} \mathrm{Si}$ diffraction peak at $1873 \mathrm{~K}$ as shown in Figure 6, is exactly in the temperature range of $1711-2449 \mathrm{~K}$ in reaction (5). Over the initial reaction temperature of $1941 \mathrm{~K}$, more and more silicon was produced by reaction (2) and dissolved into $\mathrm{Fe}_{3} \mathrm{Si}$ phase to produce $\mathrm{Fe}_{2} \mathrm{Si}$. The diffraction peak of the generated $\mathrm{Fe}_{2} \mathrm{Si}$ at $1973 \mathrm{~K}$ is found in Figure 5. The results show that the presence of iron reduces the reduction temperature of $\mathrm{SiO}_{2}$, which is consistent with findings [18]. The $\mathrm{Fe}_{3} \mathrm{Si}$ phase and the $\mathrm{Fe}_{2} \mathrm{Si}$ phase coincide well with the binary phase diagram of silicon and iron $[53,54]$. However, the FeSi phase is not found in Figure 6. It can be speculated that sufficient iron is required for the formation of Fe-Si intermetallics. Although the content of $\mathrm{SiO}_{2}$ in fly ash is more than that of $\mathrm{Fe}_{2} \mathrm{O}_{3}$, lots of $\mathrm{SiO}_{2}$ is reduced into $\mathrm{SiC}$ or $\mathrm{SiO}$. The generated $\mathrm{Fe}_{2} \mathrm{Si}$ participates in the production of $\mathrm{Al}_{9} \mathrm{FeSi}_{3}$.

AlN is found in the condensate, as shown in Figure 8. The favorable reaction path is the nitridation of aluminum by reaction (11). $\mathrm{Al}_{5} \mathrm{O}_{6} \mathrm{~N}$ can be decomposed into AlN again. The generated $\mathrm{AlN}$ reacts with $\mathrm{SiC}$ to produce $\mathrm{Al}$ by reaction (7), which is in accordance with the decrease of diffraction peak intensity of $\mathrm{SiC}$ at $2273 \mathrm{~K}$ as shown in Figure 6. Eventually, $\mathrm{Al}_{9} \mathrm{FeSi}_{3}, \mathrm{Al}$, and $\mathrm{Si}$ are obtained. According to the analysis above, a schematic diagram of phase transformation of $\mathrm{Al}_{2} \mathrm{O}_{3}, \mathrm{SiO}_{2}$, and $\mathrm{Fe}_{2} \mathrm{O}_{3}$ during carbothermic reduction of fly ash in air is presented in Figure 9. 


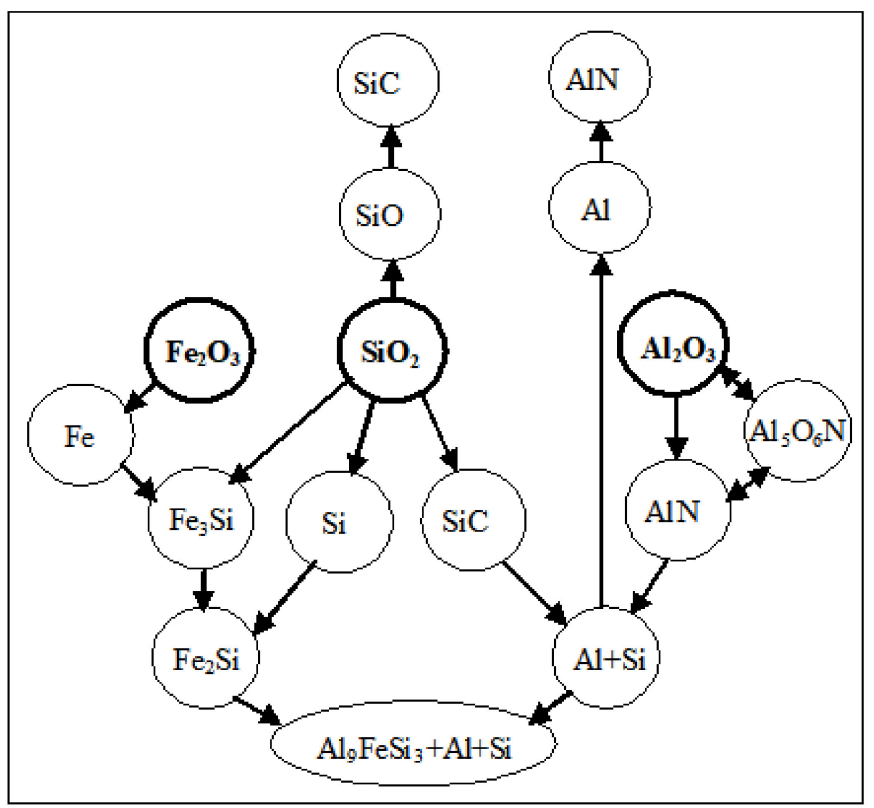

Figure 9. Schematic diagram of phase transformation.

\subsection{Comparative Analysis of Carbothermic Reduction of Fly Ash in Air and Nitrogen}

$\mathrm{SiAlON}$ is a compound containing $\mathrm{Si}, \mathrm{Al}, \mathrm{O}$, and $\mathrm{N}$. $\mathrm{Si}_{3} \mathrm{~N}_{4}$ is the matrix of $\beta$-SiAlON in which a solid solution is formed by the substitution of $\mathrm{Si}$ and $\mathrm{N}$ atoms by $\mathrm{Al}$ and $\mathrm{O}$ atoms, respectively. AlN was produced in the current study, which is consistent with the carbothermic reduction of alumina in nitrogen [55].

$\mathrm{SiC}$, instead of $\mathrm{Si}_{3} \mathrm{~N}_{4}$, is produced when silica in fly ash is reduced in air. For the synthesis of SiAlON by carbothermal reduction and nitridation, it was reported that the carbon environment of the raw materials would significantly influence the phase composition and chemical composition of the products [56]. Qiu [35] pointed out that when the carbon concentration $[C]>28 \mathrm{wt} \%$, the amount of SiAlON decreases and the $\mathrm{SiC}$ content increases. There is a weight loss during nitridation caused by escape of $\mathrm{SiO}$ and generation of $\mathrm{CO}$. In this study, carbon content was about $23 \mathrm{wt} \%$. There must be something else that plays a critical role for the synthesis of $\beta$-SiAlON. Several mechanisms have been proposed for the synthesis of $\mathrm{SiC}$, but in all of them, there is an initial stage with the formation of silicon monoxide. Generally, the accepted mechanism is the reaction of silicon monoxide with carbon (reaction 10) [57]. The mechanism is also supported by the generated $\mathrm{SiC}$ in the condensate. When fly ash is reduced by carbon in nitrogen, the gas that $\mathrm{SiO}$ can react with is restricted to nitrogen. This was supported by carbothermic reduction of silica to produce $\mathrm{Si}_{3} \mathrm{~N}_{4}$ in nitrogen [15]. When fly ash is reduced by charcoal in air, $\mathrm{Si}_{3} \mathrm{~N}_{4}$ is not produced. It is reasonable to conclude that $\mathrm{SiO}$ reacts with oxygen preferentially.

As for carbothermic reduction of fly ash in nitrogen, iron in fly ash may act as a promoting agent for the growth of a $\beta$-Sialon whisker due to its role in reducing the melting point of products [58]. However, during carbothermic reduction of fly ash in air, iron in fly ash decreases the reduction temperature of silica and participates in the formation of $\mathrm{Fe}_{3} \mathrm{Si}$ and $\mathrm{Fe}_{2} \mathrm{Si}$ phases.

Therefore, carbothermic reduction of $\mathrm{Al}_{2} \mathrm{O}_{3}$ in air is in tune with that in nitrogen, but that is not true for $\mathrm{Fe}_{2} \mathrm{O}_{3}$ and $\mathrm{SiO}_{2}$. The consequence of this effect is that carbothermic reduction of fly ash in air may not behave the same as for fly ash in nitrogen.

\section{Conclusions}

(1) The phase transformation of $\mathrm{Al}_{2} \mathrm{O}_{3}, \mathrm{SiO}_{2}$ and $\mathrm{Fe}_{2} \mathrm{O}_{3}$ can be divided into four stages, i.e., $1373 \mathrm{~K} \sim 1573 \mathrm{~K}$, reduction of $\mathrm{Fe}_{2} \mathrm{O}_{3} ; 1673 \mathrm{~K} \sim 1873 \mathrm{~K}$, decomposition of mullite and reduction of silica; $1973 \mathrm{~K} \sim 2173 \mathrm{~K}$, formation and decomposition of $\mathrm{Al}_{5} \mathrm{O}_{6} \mathrm{~N} ; 2273 \mathrm{~K}$, production of $\mathrm{Al}_{9} \mathrm{FeSi}_{3}, \mathrm{Al}$, and $\mathrm{Si}$. 
(2) During carbothermic reduction of fly ash in air, the reduction of $\mathrm{Al}_{2} \mathrm{O}_{3}$ is consistent with that in nitrogen, but that is not true for $\mathrm{Fe}_{2} \mathrm{O}_{3}$ and $\mathrm{SiO}_{2}$.

(3) With increasing temperature, $\mathrm{Fe}_{3} \mathrm{Si}$ first appears, then $\mathrm{Fe}_{2} \mathrm{Si}$ follows. The presence of Fe promotes the reduction of $\mathrm{SiO}_{2}$. No FeSi was found. The generated $\mathrm{Fe}_{2} \mathrm{Si}$ participates in the production of $\mathrm{Al}_{9} \mathrm{FeSi}_{3}$. Growth of condensate of $\mathrm{SiC}, \mathrm{AlN}$, and C follows the VLS mechanism.

(4) During carbothermic reduction of fly ash in air, much of the $\mathrm{SiO}_{2}$ is reduced into $\mathrm{SiC}$ or $\mathrm{SiO}$. $\mathrm{SiO}$ reacts with oxygen preferentially, and $\mathrm{Si}_{3} \mathrm{~N}_{4}$ was not produced. That is why $\beta$-Sialon cannot be prepared in air.

\begin{abstract}
Author Contributions: Conceptualization, Q.Y. and Z.L.; methodology, Y.D.; validation, Q.Y., Y.F. and Z.L.; formal analysis, Q.Y.; investigation, Z.L.; resources, Y.D.; data curation, Z.L.; writingoriginal draft preparation, Z.L.; writing — review and editing, Q.Y.; visualization, Z.L.; supervision, Q.Y.; project administration, Q.Y.; funding acquisition, Y.F. All authors have read and agreed to the published version of the manuscript.
\end{abstract}

Funding: This research was funded by the National Natural Science Foundation of China, grant number 51864025 .

Institutional Review Board Statement: Not applicable.

Informed Consent Statement: Not applicable.

Data Availability Statement: Ziyong Li. Preparation of Al-Si alloy by carbothermic reduction of fly ash. Master's thesis. Kunming University of Science and Technology, 2016. (In Chinese).

Acknowledgments: Authors would like to recognize the assistance provided by the Center for Analysis and Testing of Kunming University and Science and Technology. Authors also express gratitude to reviewers for helpful advices, and editorial staff for English language editing.

Conflicts of Interest: The authors declare no conflict of interest.

\title{
References
}

1. Ma, B.Y.; Li, Y.; Yan, C.; Ding, Y.S. Effects of synthesis temperature and raw materials composition on preparation of $\beta$-Sialon based composites from fly ash. Trans. Nonferrous Met. Soc. China 2012, 22, 129-133. [CrossRef]

2. Hossaonm, S.S.; Roy, P.K. Sustainable ceramics derived from solid wastes: A review. J. Asian Ceram.Soc. 2020, 9, 1-26.

3. Shoppert, A.; Valeev, D.; Loginova, I.; Chaikin, L. Complete Extraction of Amorphous Aluminosilicate from Coal Fly Ash by Alkali Leaching under Atmospheric Pressure. Metals 2020, 10, 1684. [CrossRef]

4. Valeev, D.; Kunilova, I.; Shoppert, A.; Salazar-Concha, C.; Kondratiev, A. High-pressure HCl leaching of coal ash to extract Al into a chloride solution with further use as a coagulant for water treatment. J. Clean. Prod. 2020, 276, 123206. [CrossRef]

5. Zhang, Y.D.; Li, M.; Liu, D.; Hou, X.L.; Zou, J.L.; Ma, X.T.; Shang, F.Y.; Wang, Z.W. Aluminum and iron leaching from power plant coal fly ash for preparation of polymeric aluminum ferric chloride. Environ. Technol. 2019, 40, 1568-1575. [CrossRef]

6. Tang, M.C.; Zhou, C.C.; Pan, J.H.; Zhang, N.N.; Liu, C.; Cao, S.S.; Hu, T.T.; Ji, W.S. Study on extraction of rare earth elements from coal fly ash through alkali fusion-Acid leaching. Miner. Eng. 2019, 136, 36-42. [CrossRef]

7. Zhang, W.C.; Noble, A.; Yang, X.B.; Honaker, R. A Comprehensive Review of Rare Earth Elements Recovery from Coal-Related Materials. Minerals 2020, 10, 451. [CrossRef]

8. Halmann, M.; Frei, A.; Steinfeld, A. Carbothermal reduction of alumina: Thermochemical equilibrium calculations and experimental investigation. Energy 2007, 32, 2420-2427. [CrossRef]

9. Feng, Y.B.; Yang, B.; Dai, Y.N. Research progress in carbothermal reduction of solid alumina. Chin. J. Nonferrous Met. 2013, 23, 866-872. (In Chinese)

10. Dhage, S.; Lee, H.; Hassan, M.S.; Akhtara, M.S.; Kim, C.Y.; Sohn, J.M.; Kim, K.; Shin, H.S.; Yang, O.B. Formation of SiC nanowhiskers by carbothermic reduction of silica with activated carbon. Mater. Lett. 2009, 63, 174-176. [CrossRef]

11. Fu, X.T.; Li, X.J.; Zhang, X.; Zhao, Y. Theoretical study of Al-Si alloy production by electrothermal method. Light Metals 2014, 3, 48-53. (In Chinese)

12. Kemper, C.; Balomenos, E.; Panias, D.; Paspaliaris, I.; Friedrich, B. EAF carbothermic co-reduction of alumina and silica for the direct production of Al-Si master alloy. In Light Metals; Grandfield, J., Ed.; Springer: Cham, Switzerland, 2014; pp. 789-794. [CrossRef]

13. Wang, Q.; Cui, W.; Ge, Y.Y.; Chen, K.X.; Xie, Z.P. Preparation of Spherical AlN Granules Directly by Carbothermal ReductionNitridation Method. J. Am. Ceram Soc. 2015, 98, 392-397. [CrossRef]

14. Forslund, B.; Zheng, J. Carbothermal synthesis of aluminum nitride at elevated nitrogen pressures. Part I. Effect of process parameters on conversion rate. J. Mater. Sci. 1993, 28, 3125-3131. [CrossRef] 
15. Hu, Y.C.; Li, S.M.; Shan, S.Y.; Jia, Q.M.; Jiang, L.H.; Wang, Y.M. Research Progress of Silicon Nitride Prepared by Carbothermal Reduction Method. B. Chin. Ceram. Soc. 2012, 31, 1165-1169. (In Chinese)

16. Vlasova, M.V.; Bartnitskaya, T.S.; Sukhikh, L.L.; Krushinskaya, L.A.; Tomila, T.V.; Artyuch, S.Y. Mechanism of $\mathrm{Si}_{3} \mathrm{~N}_{4}$ nucleation during carbothermal reduction of silica. J. Mater. Sci. 1995, 30, 5263-5271. [CrossRef]

17. Bai, Z.L.; Qin, B.K.; Lian, M.L. Study on the Preparation of Si-Al Alloy by Carbon Reduction Coal Fly Ash. 7th International Conference on Energy and Environmental Protection. Adv. Eng. Res. 2018, 170, 1139-1142. [CrossRef]

18. Yang, D.B.; Yao, H.Q.; MA, G.J.; Ao, W.Z.; Wan, G.X.; Zhang, D.S. Production of Si-Al alloy with carbothermal reduction of fly ash from thermal power plant. Renew. Resour. Circu. Eco. 2011, 4, 33-36. (In Chinese)

19. Zhang, X.F. Test study of electric heat reducing high aluminum powder to extracted Fe-Al-Si. Ferro-Alloys 2005, 36, 11-15. (In Chinese)

20. Jiang, H.X.; Sun, S.C.; Zhang, L.F. Experiment on production of Al-Si-Fe alloy with fly ash and bauxite by electrothermal method. Ferro-alloys 2003, 3, 23-27. (In Chinese)

21. Zhu, J.; Yan, H. Microstructure and properties of mullite-based porous ceramics produced from coal fly ash with added $\mathrm{Al}_{2} \mathrm{O}_{3}$. Int. J. Miner. Metall. Mater. 2017, 24, 309-315. [CrossRef]

22. Yin, Y.; Ma, B.; Li, S.; Zhang, B.; Yu, J.; Zhang, Z.; Li, G. Synthesis of $\mathrm{Al}_{2} \mathrm{O}_{3}-\mathrm{SiC}$ composite powders from coal ash in $\mathrm{NaCl}-\mathrm{KCl}$ molten salts medium. Ceram. Int. 2016, 42, 19225-19230. [CrossRef]

23. Wang, W.; Chen, W.; Liu, H. Recycling of waste red mud for fabrication of SiC/mullite composite porous ceramics. Ceram. Int. 2019, 45, 9852-9857. [CrossRef]

24. Gilbert, J.E.; Mosset, A. Preparation of $\beta$-SiAlON from Fly Ashes. Mater. Res. Bull 1998, 33, 117-123. [CrossRef]

25. Qiu, Q.; Hlavacek, V. Carbonitridation of fly ash. II. Effect of decomposable additives and whisker formation. Ind. Eng. Chem. Res. 2005, 44, 2477-2483. [CrossRef]

26. Fang, M.H.; Liu, H.T.; Huang, Z.H.; Huang, J.T.; Liu, Y.G.; Zhang, S.W. Phase transformation of high aluminium fly ash in carbothermal reduction-nitridation at high temperatures. Mater. High Tem. 2015, 32, 399-403. [CrossRef]

27. Zhao, H.; Wang, P.Y.; Yu, J.L.; Zhang, J. A mechanistic study on the synthesis of $\beta$-Sialon whiskers from coal fly Ash. Mater. Res. Bull. 2015, 65, 47-52. [CrossRef]

28. Lu, X.Y.; Zhang, D.; Cai, S.Z. Study on synthesizing SiAlON powders from fly ashes. Refractories 2005, 39, 259-262.

29. Luo, Y.; Zheng, S.L.; Ma, S.H.; Liu, C.L.; Ding, J.; Wang, X.H. Novel two-step process for synthesising $\beta$-SiC whiskers from coal fly ash and water glass. Ceram. Int. 2018, 44, 10585-10595. [CrossRef]

30. Pesl, J.; Eric, R.H. High temperature carbothermic reduction of $\mathrm{Fe}_{2} \mathrm{O}_{3}-\mathrm{TiO}_{2}-\mathrm{M}_{\mathrm{x}} \mathrm{O}_{\mathrm{y}}$ oxide mixtures. Min. Eng. 2002, 15, 971-984. [CrossRef]

31. Chung, F.H. Quantitative interpretation of X-ray diffraction patterns of mixtures. I. Matrix-flushing method for quantitative multicomponent analysis. J. Appl. Cryst. 1974, 7, 519-525. [CrossRef]

32. Chung, F.H. Quantitative interpretation of X-ray diffraction patterns of mixtures. II. Adiabatic principle of X-ray diffraction analysis of mixtures. J. Appl. Cryst. 1974, 7, 526-531. [CrossRef]

33. Wood Charcoal and Test Method of Wood Charcoal. GB/T 17664-1999. Available online: https://max.book118.com/html/2017 /0725/124182768.shtm (accessed on 12 July 2021).

34. Tomeczek, J.; Palugniok, H. Kinetics of mineral matter transformation during coal combustion. Fuel 2002, 81, 1251-1258. [CrossRef]

35. Qiu, Q.; Hlavacek, V.; Prochazka, S. Carbonitridation of Fly Ash. I. Synthesis of SiAlON-Based Materials. Ind. Eng. Chem. Res. 2005, 44, 2469-2476. [CrossRef]

36. Pickles, C.A. Thermodynamic analysis of the selective carbothermic reduction of electric arc furnace dust. J. Hazard. Mater. 2008, 150, 265-278. [CrossRef] [PubMed]

37. Available online: http:/ / baike.mysteel.com/doc/view/46508.html (accessed on 12 July 2021).

38. Ding, Y.L.; Warner, N.A. Catalytic reduction of carbon-chromite composite pellets by lime. Thermochim. Acta. 1997, 292, 85-94. [CrossRef]

39. Chen, X.M. Theoretical Study on Chlorination Disproportionation of Alumina by Carbothermal Reduction in Vacuum. Ph.D. Thesis, Kunming University of Science and Technology, Kunming, China, 2012. (In Chinese)

40. Zhao, Y.; Shen, Q.; Wang, C.B.; Zhang, L.M. Investigation of mechanical alloying process of Fe-Si. Powder Met. Tech. 2006, 24, 407-411. (In Chinese) [CrossRef]

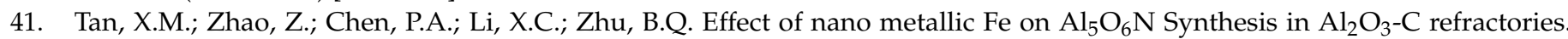
Interceram Inter. Ceram. Rev. 2015, 64, 108-111. [CrossRef]

42. Bandyopadhyay, S.; Mukerji, J. Reaction sequences in the synthesis of silicon nitride from quartz. Ceram. Inter. 1991, 17, 171-179. [CrossRef]

43. Wei, C.C.; Tian, G.S. Synthesis technology of spinel AlON. Trans. Nonfer Met. Soc. China 2007, 17, 152-155. (In Chinese)

44. Liu, X.J.; Chen, F.; Zhang, F.; Zhang, H.L.; Zhang, Z.; Wang, J.; Wang, S.W.; Huang, Z.R. Hard transparent AlON ceramic for visible/IR windows. Int. J. Refract. Met. Hard Mater. 2013, 39, 38-43. [CrossRef]

45. Song, Y.F.; Wang, S.H.; Deng, C.J.; Zhu, H.X. Effect of nitridizing holding time on properties of in-situ synthesized AlON bonded $\mathrm{MgAl}_{2} \mathrm{O}_{4}$-C refractories. Refractories 2017, 51, 181-185. (In Chinese) 
46. Chen, W.Y.; Wan, S.L.; Shi, G. Stable oxides on chars and impact of reactor materials at high temperatures. Energ. Fuel. 2007, 21, 778-792. [CrossRef]

47. Dai, Y.N.; Yang, B. Vacuum Metallurgy of Nonferrous Materials; Metallurgical Industry Press: Beijing, China, $1999 ;$ pp. $220-235$.

48. Besisa, D.H.A.; Ewais, E.M.M.; Ahmed, Y.M.Z.; Elhosiny, F.I.; Kuznetsov, D.V.; Fend, T. Densification and characterization of SiC-AlN composites for solar energy applications. Renew. Energ. 2018, 129, 201-213. [CrossRef]

49. Dubois, J.; Murat, M.; Amroune, A.; Carbonneau, X.; Gardon, R.; Kannan, T.S. High-temperature carboreduction of kaolins of different crystallinity. Appl. Clay Sci. 1998, 13, 1-12. [CrossRef]

50. Ren, K.G.; Chen, K.X.; Zhou, H.P.; Ning, X.S.; Jin, H.B.; Zhong, J.D. Synthesis of SiC nanowires in fluidized bed and its microstructure. Rare Metal Mater. Eng. 2009, 38, 52-54. (In Chinese)

51. Bechtold, B.C.; Cutler, I.B. Reaction of Clay and Carbon to Form and Separate $\mathrm{Al}_{2} \mathrm{O}_{3}$ and SiC. J. Am. Ceram. Soc. 2006, 63, 271-275. [CrossRef]

52. Chen, H.K.; Lin, C.I.; Lee, C. Mechanism of the reduction of carbon/alumina powder mixture in a flowing nitrogen stream. J. Mater. Sci. 1994, 29, 1352-1357. [CrossRef]

53. Dai, Y.N. Binary Alloy Phase Diagrams; Science Press: Beijing, China, 2009; p. 219. (In Chinese)

54. Available online: http://muchong.com/html/201602/9985885.html (accessed on 10 December 2019). (In Chinese)

55. Qi, S.; Mao, X.J.; Li, X.K.; Feng, M.H.; Jiang, B.X.; Zhang, L. Synthesis of AlN hexagonal bipyramids by carbothermal reduction nitridation. Mater. Lett. 2016, 174, 167-170. [CrossRef]

56. Dou, K.Z.; Jiang, Y.S.; Xue, B.; Wei, C.D.; Li, F.F. The carbon environment effects on phase composition and photoluminescence properties of $\beta$-SiAlON multiphase materials prepared from fly ash acid slag. Ceram. Inter. 2019, 45, 7850-7856. [CrossRef]

57. Wang, H.; Wang, Y.; Jin, Z. SiC powders prepared from fly ash. J. Mater. Process. Technol. 2001, 117, 52-55. [CrossRef]

58. Yu, J.K.; Ueno, S.; Hiragushi, K.; Zhang, S.W. Synthesis of $\beta-S i A l O N$ Whiskers from Pyrophyllite. J. Ceram. Soc. Jpn. 1997, 105, 821-823. [CrossRef] 